\title{
FORUM
}

Submitted 07.07.2020. Approved 11.12.2020

Evaluated through a double-blind review process. Guest Editors: Alessandra de Sá Mello da Costa, Ely Laureano Paiva, Marcus Vinícius Peinado Gomes and Vinicius Brei

Original version

DOI: http://dx.doi.org/10.1590/So034-759020200606

\section{THE BURNOUT EPIDEMIC DURING THE COVID-19 PANDEMIC: THE ROLE OF LMX IN ALLEVIATING PHYSICIANS' BURNOUT}

\author{
Epidemia de Burnout durante a pandemia de Covid-19: O papel da LMX na \\ redução do burnout dos médicos \\ La Epidemia de Burnout durante la Pandemia de COVID-19: El papel del LMX en \\ la reducción del estrés crónico de los médicos
}

\begin{abstract}
During COVID-19 pandemic, physicians are being exposed to unprecedented adverse working conditions that lead to increased occurrence of burnout. While supportive leadership is considered effective in preventing bur nout, little is known about the role of leadership in extreme situations. Drawing on leader-member exchange $(L M X)$ theory, we hypothesize that high-LMX relationships lead to lower levels of burnout, as they shape physicians' perceptions of psychosocial job demands and resources. We also contend that this effect will be stronger for frontline physicians, as they are more exposed to job stressors. In a field study with 2,708 Brazilian physicians, we found support to the alleviating role of $L M X$, but contrary to what we predicted, we found that this effect is weaker for frontline physicians. Overall, our findings reinforce the importance of establishing highquality relationships between supervisors and medical staff to mitigate the experience of burnout, however, they also highlight that extreme conditions, such as the COVID-19 pandemic, might constrain the beneficial effects of leadership behaviors.
\end{abstract}

KEYWORDS | Leadership, LMX, Burnout, COVID-19, healthcare workers.

\section{RESUMO}

Durante a pandemia de Covid-19, os médicos estão expostos a condições adversas de trabalho que têm levado ao aumento da ocorrência de burnout entre esses profissionais. Embora o suporte da liderança seja considerado eficaz na prevenção do burnout, pouco se sabe sobre o papel da liderança em situações extremas. Com base na teoria da troca de líder e membro (LMX), propomos que um relacionamento de alta qualidade entre supervisores e médicos pode reduzir os níveis de burnout dos médicos, uma vez que moldam as percepções destes sobre as demandas e recursos psicossociais do trabalho. Acreditamos que esse efeito será mais forte para os médicos que atuam na linha de frente, pois eles estão mais expostos a estressores no trabalho. Em um estudo de campo com 2.708 médicos brasileiros, encontramos apoio ao papel da LMX na mitigação do burnout. De modo geral, nossas descobertas reforçam a importância de estabelecer relacionamentos de alta qualidade entre supervisores e equipe médica para mitigar a experiência do esgotamento; no entanto, também destacam que condições extremas, como a pandemia de Covid-19, podem restringir os efeitos benéficos dos comportamentos de liderança. PALAVRAS-CHAVE / Liderança, LMX, Burnout, Covid-19, profissionais de saúde.

\section{RESUMEN}

Durante la pandemia de COVID-19, los médicos están expuestos a condiciones laborales adversas que han llevado a un aumento del surgimiento del síndrome de burnout entre estos profesionales. Aunque el apoyo del liderazgo se considere efectivo para prevenir el agotamiento laboral, se sabe poco sobre el papel del lide razgo en situaciones extremas. Con base en la teoría del cambio de líder y miembro (LMX), proponemos que una relación de alta calidad entre los supervisores y los médicos puede reducir los niveles de burnout de los médicos, ya que moldean sus percepciones sobre las demandas y recursos psicosociales del trabajo. Creemos que este efecto será más fuerte para los médicos que trabajan en primera línea, ya que están más expuestos a los estresores laborales. En un estudio de campo con 2.708 médicos brasileños, encontramos apoyo al papel del LMX en la mitigación del síndrome de burnout. En general, nuestros hallazgos refuerzan la importancia de establecer relaciones de alta calidad entre los supervisores y el personal médico para mitigar la experiencia del agotamiento, sin embargo, también destacan que las condiciones extremas, como la pandemia de COVID-19, pueden restringir los efectos beneficiosos de los comportamientos de liderazgo.

PALABRAS CLAVE / Liderazgo, LMX, Burnout, COVID-19, trabajadores sanitarios 


\section{INTRODUCTION}

The coronavirus outbreak has created unique challenges for workers worldwide. While the majority of the workforce was asked to work from home to help "flatten the curve", healthcare workers were requested to remain in the frontline, working long hours to fight this deadly threat, even if they do not have enough appropriate conditions in terms of structure, personal protection equipment and training (Fernandes \& Pereira, 2020; Peci, 2020; Silva, Saraiva, Ferreira, Peixoto Junior \& Ferreira, 2020). By doing so, these professionals are not only risking exposure to the virus but also facing the risk of burnout syndrome, a job stress-related disorder in which employees feel emotionally "spent" and disengaged towards their work (Halbesleben \& Buckley, 2004). Indeed, studies have shown that, by exacerbating stressors from an underprepared healthcare system as well as adding unique new ones associated with the uncertain scenario, the coronavirus pandemic has prompted a spike of burnout among primary healthcare workers, particularly physicians (Bansal et al., 2020; Restauri \& Sheridan, 2020). Thus, it has become even more crucial during these extraordinary times to identify effective ways of reducing stressors in order to prevent burnout among health care workers.

Research has shown that supportive leadership can be effective in mitigating burnout through its effects on workplace stressors (Halbesleben \& Buckley, 2004). In this respect, leader-member exchange (LMX) theory seems to be particularly appropriate (Thomas \& Lankau, 2009). From the perspective of job demands-resources (JD-R) model (Bakker \& Demerouti, 2007), high-quality LMX relationships are considered sources of greater social support and resources, which help employees to better cope with their job demands, workplace stressors and the associated physiological and psychological costs (Thomas \& Lankau, 2009). As such, employees who have high-quality LMX relationships are likely to successfully respond to the demands that could otherwise foster emotional exhaustion and disengagement at work.

Indeed, previous studies have yielded evidence indicating the importance of LMX-related resources for subordinates' health and well-being when facing adverse situations (Dicke, Stebner, Linninger, Kunter, \& Leutner, 2018; Tummers \& Knies, 2013). For example, Montani, Courcy, and Vandenberghe (2017) study found that when LMX was high, the positive effects of challenge stressors on effective work attitudes and behaviors were enhanced, while the negative effects of hindrance stressors were attenuated. Similarly, in a study with healthcare professionals working in different hospitals, Hesselgreaves and Scholarios (2014) found that LMX reduced job demands and strain for junior subordinates.

Our study examines the role of leadership in attenuating physicians' burnout in the extreme context of the COVID19 pandemic. Specifically, using data from 2,708 physicians working in the Brazilian healthcare system during the pandemic, we investigate if and how LMX relationships can reduce the experience of burnout among medical doctors, particularly the ones working in the frontline. Because extreme contexts create unique contingencies and constraints that can be a lever for counterfactual reasoning (Hällgren, Rouleau, \& Rond, 2018), we believe that examining the relationship between LMX and burnout in such contexts can yield valuable insights to leadership literature, since previously established findings in 'normal' settings may not be generalized to extreme contexts (Hannah, Uhl-Bien, Avolio, \& Cavarretta, 2009).

\section{THEORETICAL BACKGROUND}

Media reports and empirical research have been highlighting that primary healthcare workers are being exposed to unprecedented levels of burnout during the struggle against COVID-19 (Bansal et al., 2020; Restauri \& Sheridan, 2020). They have to deal not only with the risks of exposure to the virus, but also with adverse working conditions such as increased responsibilities, lack of resources, work overload, and high rates of death and trauma in the workplace. Because healthcare professionals are immersed in such an extreme context, they do not have opportunities to replenish cognitive and emotional resources depleted by those stressful conditions. As such, they are particularly susceptible to develop psychological syndromes such as burnout (Sonnentag, Kuttler, \& Fritz, 2010).

Defined as a prolonged response to chronic emotional and interpersonal stressors on the job, burnout syndrome is considered an occupational hazard (Maslach, Schaufeli, \& Leiter, 2001). While scholars somewhat differ in its conceptualization, they agree that burned-out employees are mainly characterized by feelings of energy depletion or exhaustion and negative attitudes toward their work (Demerouti, Mostert, \& Bakker, 2010). Empirical research has shown that burnout is a potential consequence of excessive job demands, role ambiguity and conflicts, and poor social support (Maslach et al., 2001). In this respect, scholars have argued that leadership may play a key role in preventing burnout (Halbesleben \& Buckley, 2004; Harms, Credé, Tynan, Leon, \& Jeung, 2017) since all these work-related factors can be influenced by supportive leadership behaviors. Nevertheless, 
relatively little attention has been paid to the link between $L M X$ and burnout (Schermuly \& Meyer, 2015; Thomas \& Lankau, 2009). Interestingly, LMX researchers have advanced the notion that LMX may affect the two core components of burnout: emotional exhaustion, which "refers to feelings of being overextended and depleted of one's emotional and physical resources" (Maslach \& Leiter, 2008, p. 498) and disengagement, defined as "distancing oneself from one's work, and experiencing negative attitudes toward the work object, work content, or one's work in general" (Demerouti, Bakker, Nachreiner, \& Schaufeli, p. 501). The theoretical explanations for such impact are related to the fact that LMX relationships are important sources of jobrelated social support and resources (Gerstner \& Day, 1997). As contended by the extant LMX literature, in a high-quality LMX relationship, leaders provide many tangible and intangible resources to subordinates, including attention, support, time, empowerment, information sharing, autonomy (Gottfredson, Wright, \& Heaphy, 2020). Low-LMX subordinates, in contrast, receive fewer resources as "low-quality relationships have been said to be mainly transactional and based on the hierarchical authority of the supervisor" (Epitropaki et al., 2016, p. 1079).

In this regard, LMX should play a key role in influencing subordinates' emotional exhaustion. In general, the physical and mental effort expended by day-to-day reactions to workplace stressors drains employees' resources and leads to negative outcomes as fatigue and emotional exhaustion (Hobfoll, 2002). Those better endowed with resources are less negatively affected by the resource drain or loss that accompanies stressful conditions. Therefore, as leaders grant more resources to highLMX members than they grant to low-LMX ones, we can expect that the increased level of resources makes resources depletion and emotional exhaustion less likely among high-LMX members. Conversely, a poor provision of resources can result in a faster depletion and feelings of exhaustion (Hobfoll, 2002). Further, the social-emotional resources and support provided by leaders in high-LMX relationships have been identified as a critical factor in attenuating perceptions of an extreme event, such as the current COVID-19 pandemic, by increasing one's ability to cope with it, and thus helping to mitigate emotional consequences, such as exhaustion (Hannah et al., 2009).

In addition, several studies have demonstrated that LMXrelated resources, such as autonomy and social support, may function as drivers of a process that leads to work engagement while a low level of job resources results in disengagement at work (Bakker \& Demerouti, 2007; Demerouti et al., 2001). Therefore, $L M X$ also plays a pivotal role in preventing work disengagement. $A$ strong, high-quality relationship with the leader provides greater access to resources, thus energizing individuals and facilitating the accomplishment of work goals. Accordingly, it is likely that employees feel more engaged. Moreover, it has been shown that leaders in high-quality $L M X$ relationships give their followers more intrinsic and extrinsic rewards, which result in more positive attitudes toward work (Epitropaki \& Martin, 2005). Employees will also have more opportunities for personal growth, learning, and development (Bakker \& Demerouti, 2007). Such resources emanating from the leader impact employee work engagement positively by playing an instrumental role in both intrinsic and extrinsic motivation (Bakker \& Demerouti, 2008). Thus, we posit that physicians with high LMX quality with their direct supervisor will experience lower levels of burnout (emotional exhaustion and disengagement) during the COVID-19 pandemic.

$\mathrm{H}_{1}$ : LMX quality is negatively related to burnout.

The JD-R model of burnout (Demerouti et al., 2001) predicts that the development of burnout follows two processes. The first process involves extreme job demands that lead to constant overtaxing and, in the end, to emotional exhaustion. The second process is related to a lack of resources that thwarts the meeting of job demands, thereby leading to withdrawal behaviors, such as disengagement. Thus, we argue that the effect of LMX on alleviating burnout occurs through its influence on employees' perceptions of the psychosocial job demands and resources, which encompass perceptions regarding social support, psychological demands and job control.

High-quality leader-member exchanges (LMX) are considered sources of greater social support (Graen \& UhlBien, 1995), defined as "an interpersonal transaction that involves emotional concern, instrumental aid, information, or appraisal" (Carlson \& Perrewé, 1999, p. 514). Social support helps employees to better address their job demands and the associated psychological and psychosocial costs by providing attention, interaction, and the exchange of information and resources (Thomas \& Lankau, 2009). Moreover, social support increases feelings of protection, self-efficacy, and belongingness, which contributes to face job requirements and role demands positively. For example, as showed by Siu, Lu, and Spector (2007), self-efficacy serves as a resource factor that should buffer against stressor perceptions such that employees are likely to perceive a demanding work environment as more challenging than threatening.

Moreover, a high-LMX relationship may lead employees to interpret work demands differently. With the help and support of the leader, high-LMX employees may experience less role conflict and enjoy their jobs more (Gerstner \& Day, 1997). Similarly, because 
these employees enjoy a more supportive work environment, they internalize less work pressure and tension, making work seem less demanding (Bakker, Demerouti, \& Euwema, 2005).

In addition, high-quality relationships with the leader have been identified as one of the most central sources of job control (Gottfredson et al., 2020), such as greater decision-making latitude and autonomy (Gerstner \& Day, 1997; Harms et al., 2017; Hetland, Sandal, \& Johnsen, 2007). In fact, these relationships have been shown to give broader negotiating latitude to workers over their work, thus allowing them to experience greater control and reduce the number or the difficulty of their assignments. For example, Tordera, González-Romá, and Peiró (2008) showed that employees who reported high-quality LMX tended to report lower levels of role overload. Relatedly, Trépanier, Fernet, and Austin (2013) found that employees with high autonomy experience less psychological distress in the presence of job demands than their less autonomously motivated counterparts.

In sum, we contend that LMX directly influences how job demands and resources are perceived and interpreted; specifically, we argue that when a high-quality $L M X$ is maintained, employees perceive job demands more favorably as well as they feel more in control over their tasks and their conduct during the working day. Hence, we hypothesize the following:

H2: Psychosocial job demands and resources mediate the relationships between LMX and burnout.

Finally, it should be noted that, although the COVID-19 pandemic has undoubtedly created a harsh environment for medical doctors in general, those who are caring directly for patients with COVID-19 (i.e., frontline physicians) are likely to experience even higher risks, anxiety, demands and stress than those in less exposed roles. In addition to a higher risk of infection, frontline physicians are being demanded to make every possible effort to save lives in an inescapable context of pressures, uncertainty, pain, suffering, and deaths. Some studies looking at frontline physicians during COVID-19 have shown that these professionals experience unique stressors (e.g., the stigma of working with coronavirus patients, the concern about personal protective equipment) which put them at risk of profound resource depletion and mental exhaustion (Lu, Wang, Lin, \& Li, 2020). For example, the lack of personal protective equipment (PPE) and training on how to use new equipment causes many frontline professionals to question whether they have been exposed, and some hesitate to go home in fear of exposing family members to infection (Sasangohar, Jones, Masud, Vahidy, \& Kash, 2020).

In such a case, the beneficial effects of high LMX relationships in providing resources and reducing demands may be even stronger. Consequently, we hypothesize that LMX relationships involving frontline physicians will have a stronger impact on their psychosocial demands and resources, and thus, on their experience of burnout than those working in less exposed positions. We thus propose:

H3: The indirect effect of LMX on burnout through Psychosocial job demands and resources is moderated by frontline vs. non-frontline employees, such that the relationship is stronger for frontline physicians than for non-frontline ones.

\section{METHODS}

\section{Sample and procedures}

Participants were recruited in collaboration with PEBMED, a Brazilian company specialized in developing clinical solutions to support and facilitate physicians' decision-making. Invitations were sent through email to a sample of Brazilian physicians of diverse specialties. A total of 2,708 physicians fully answered the survey. Participants were, on average, 38 years old (range 21-78), $66 \%$ were female, and $70 \%$ declared themselves as religious people. The majority $(2,417 ; 89 \%)$ reported having a fear of transmitting COVID-19 to their family, and $12 \%$ (346) stated having already been diagnosed with the virus. Approximately $70 \%(1,875)$ declared themselves as being in the frontline of care to patients with confirmed or suspected infection of coronavirus, and $88.5 \%$ reported working in a healthcare facility that receives patients with COVID-19. Regarding the type of facility, 1,936 declared working in public, 706 in private, and 66 in beneficent facilities.

The study was carried out in accordance with the recommendations of the institutional ethical compliance committee on research involving human beings of the institution at which most of the authors were located at the time of data collection. Further, participants were provided a term of informed consent to participate and publish the data in accordance with the Declaration of Helsinki.

\section{Measures}

Burnout syndrome. Burnout, our dependent variable, was measured by the Oldenburg Burnout Inventory (OLBI), developed by Halbesleben and Demerouti (2005), translated and validated to Portuguese by Schuster and Dias (2018). The OLBI has two dimensions: exhaustion (8 items) and disengagement (8 items) 
and was measured on a Likert scale ranging from 1 (strongly disagree) to 5 (strongly agree). Exhaustion is defined as a consequence of intensive physical, affective and cognitive strain, that is, as a long-term consequence of prolonged exposure to certain job demands. A sample item is: "There are days when I feel tired before I arrive at work." Disengagement refers to distancing oneself from one's work in general, work object, and work content. Moreover, the disengagement-items concern the relationship between employees and their jobs, particularly with respect to identification with work and willingness to continue in the same occupation. A sample item is: "Lately, I tend to think less at work and do my job almost mechanically." We computed the OLBI index as a simple average of these two dimensions (some items were reverse-coded when appropriate), keeping its interpretation that the higher the OLBI index, the higher the probability of burnout. The reliability of this scale was .91 .

Job Demands and Resources. The psychosocial job demands and resources were measured by a shorter version of the Job Content Questionnaire (JCQ), originally developed by Karasek and Theorell (1990), validated to Portuguese by Alves, Chor, Faerstein, Lopes, and Werneck (2004). The scale contains three dimensions: psychological demands ( 5 items), job control (6 items), and social support (6 items). Psychological Demands refers to pressures of psychological nature in the work environment (e.g., “Do you have to work very intensively?”). Job Control refers to decision latitude and the degree of authority (e.g., “Do you have a choice in deciding HOW you do your work?"). Social Support captures the level of social interaction between worker and his/her colleagues and superiors (e.g., "I enjoy working with my co-workers"). The first two dimensions use a 4-point frequency scale, and the social support uses a 4-point Likert scale. Each dimension was separately calculated, as recommended by authors, as an average of the responses (job control and social support dimensions were reversely rated). To get a single measure, we took a simple average of the three dimensions, such that the higher the index, the higher the psychosocial job demand. The reliability of this scale was.81.

Leader-Member Exchange. LMX, our independent variable, was measured by the nine-item LMX-MDM scale (Liden \& Maslyn, 1998), translated and validated to Portuguese by Côrtes, Souza, and Puente-Palacios (2019). The scale has three dimensions: Affection, Loyalty, and Professional Respect. Affection evaluates the subordinate's friendship and liking toward the leader (e.g., "I really like my leader as a person"), Loyalty evaluates the amount of loyalty that the subordinate feels the leader has toward him or her (e.g., "My leader comes to my defense"), and Professional Respect assesses the respect and admiration the subordinate feels regarding his or her leader's job knowledge or competence (e.g., "I am impressed with my leader's knowledge"). Responses were gathered on a 7-point Likert scale, ranging from 1 (strongly disagree) to 7 (strongly agree). The overall quality of LMX was calculated as a simple average of the items. The reliability of this scale was .94 .

Participants were asked to inform if they work in the frontline of treatment of COVID-19 patients, with a single question: "Do you work in the frontline of treatment of COVID-19 suspected or confirmed patients?”.

Controls. As controls, we included several individual characteristics, such as gender, age, fear of transmitting coronavirus to family, religiosity, previous diagnosis of COVID-19, and working hours per week; and characteristics of the healthcare facility: private, public, or beneficent, and status of COVID-19 patients. Finally, we also included a single measure of positive and negative activation using the Lebender Emoticon PANAVA scale (Schreibera \& Jenny, 2020), as positive and negative affection have been shown to influence subordinates' perceptions of leadership and job demands, thus mitigating some commonmethod concerns.

\section{RESULTS}

Before testing our hypotheses, we conducted a confirmatory factor analysis (CFA) to establish the discriminant validity of our measurement model. Results of the three-factor model (LMX, job demands, and burnout) suggest a good fit $(\mathrm{CFI}=0.94 ; \mathrm{TLI}=0.91$; RMSEA $=0.09$ ), significantly better than alternative models of two and one factor, thus supporting our proposed model. Table 1 presents means, standard deviations and correlations between the study's constructs.

We tested our hypotheses using OLS linear regressions. We first tested the models with burnout as our dependent variable. Table 2 presents the results, which show that LMX is negatively related to burnout $(b=-.063, \mathrm{SE}=.004, p<.001$; Model 2), thus corroborating $\mathrm{H}_{1}$. Also, results show that by including job demands in the model $(b=.563, S E=.024, p<.001$; Model 4$)$, the strength of the effect of LMX on burnout is reduced, which suggests a partial mediation. To examine this possibility, we conducted a mediation analysis using bootstrapped standard errors (5000 replications). Corroborating $\mathrm{H}_{2}$, we found that the average indirect effect of $L M X$ on burnout is negative and significant ( $b=-.040, S E=.004, p<.01$; see Table 2). Further supporting this mediation, we found that LMX is significantly and negatively related to job demands $(b=-.070, S E=0.03, p<$ 
.001). These results suggest that LMX can reduce burnout by alleviating physicians' perceptions of their psychosocial job demands and providing them social support.

Table 1. Means, standard deviations and correlations

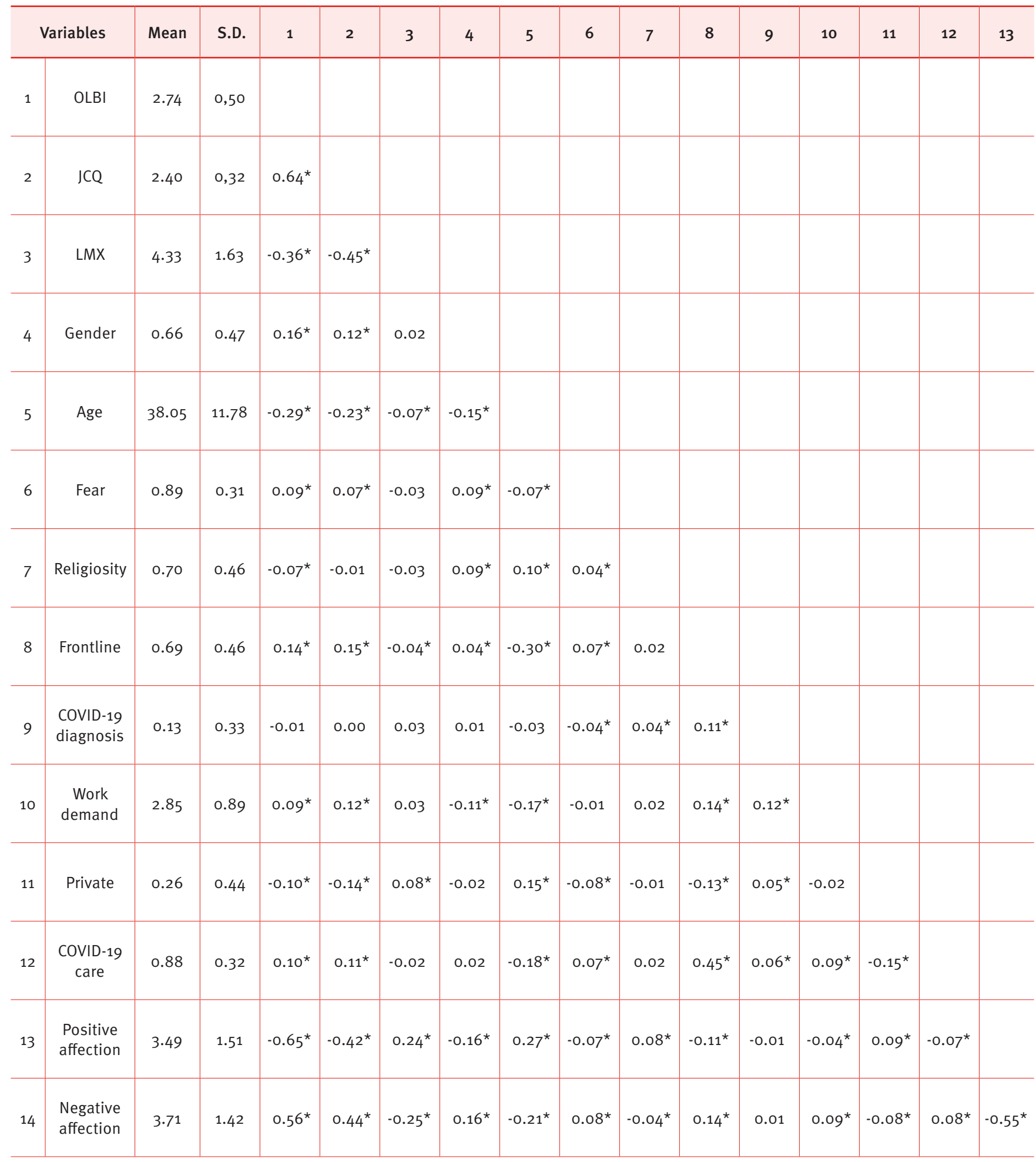

Notes. $\mathrm{N}=2,708$. Frontline/Fear/Covid-19 previous diagnosis/Covid-19 attendance: 0-No / 1-Yes; Gender: o-Male / 1=Female 
Table 2. Regression models predicting burnout

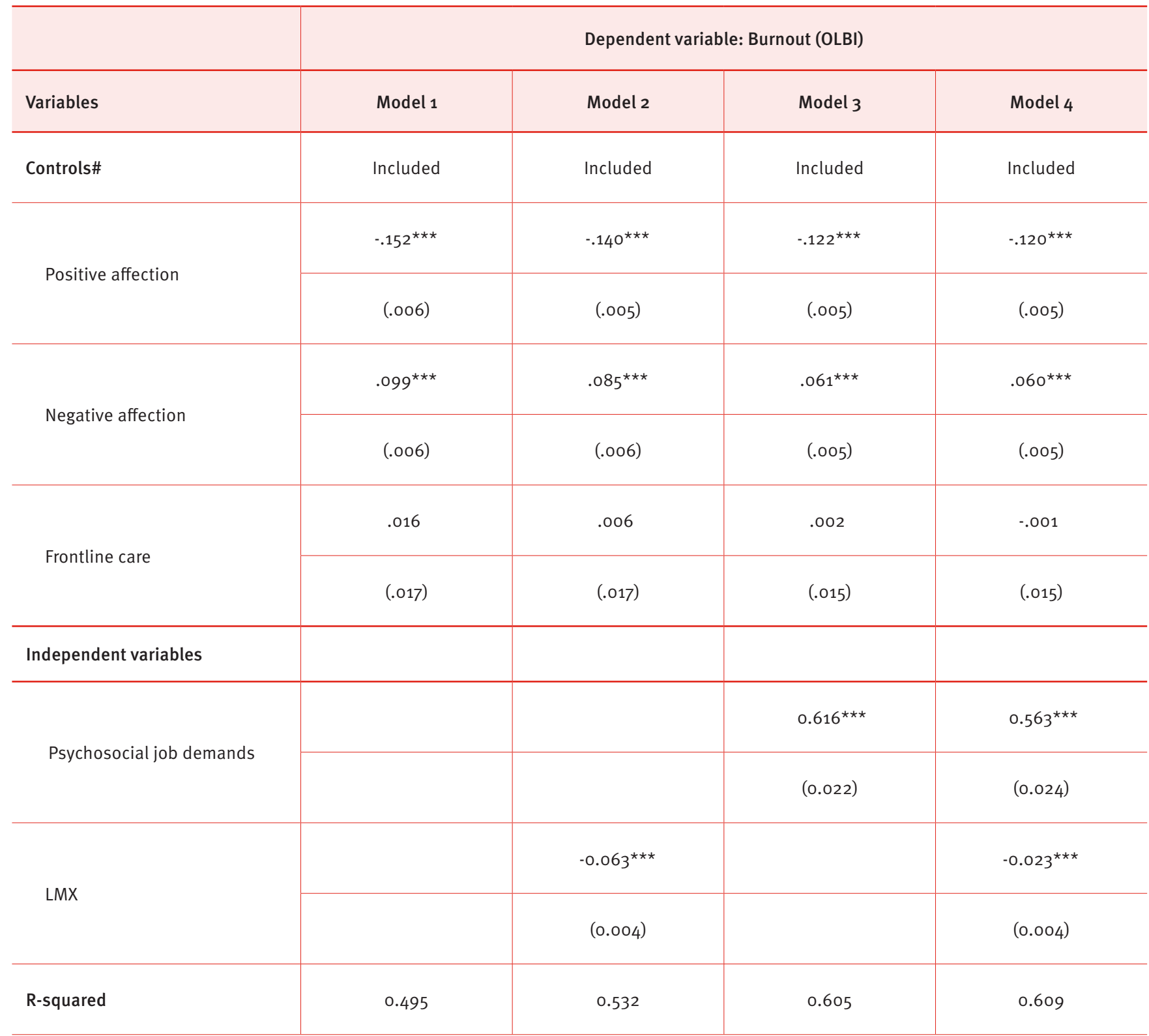

\# We included all controls in the analyses.

$\mathrm{n}=2,708 ;{ }^{*} \mathrm{p}<.05^{* \star} \mathrm{p}<.01{ }^{* \star *} \mathrm{p}<.001$; Standard errors in parentheses.

Finally, $\mathrm{H}_{3}$ predicted that these effects of $L M X$ on burnout would be stronger for physicians in the frontline against COVID19. Contrary to our hypothesis, our results showed a positive moderating effect of frontline care on the relationship between LMX and psychosocial job demands and resources $(b=.017, \mathrm{SE}=$ $.006, p<.01)$. Surprisingly, being in frontline seems to attenuate the effect of LMX on decreasing the perception of job demands. This result might be explained by the extreme conditions of pandemics as an adverse environment for leaders to exert influence. To test the indirect effect of LMX on burnout for both physicians acting in the frontline or less exposed roles, we conducted conditional path analysis (moderated mediation) with bootstrapped standard errors (5,000 replications). Our results revealed that the indirect effect of LMX on burnout was significant for both physicians working in the frontline $(b=-.037, S E=0.002)$ as well for the ones in less exposed positions $(b=-.046, \mathrm{SE}=.004)$; however, the effect was stronger for the ones not working directly with COVID-19 patients. Table 3 presents the results for the indirect effects of $L M X$ on burnout. 
Table 3. Mediation and moderated mediation estimates on burnout

\begin{tabular}{|c|c|c|c|c|}
\hline Average indirect effect & -.040 & .004 & -.040 & -.039 \\
\hline \multicolumn{5}{|l|}{ Conditional indirect effect } \\
\hline Non-frontline physicians & -.046 & .004 & -.055 & -.038 \\
\hline
\end{tabular}

$n=2,708 ;{ }^{*} p<.05^{* *} p<.01{ }^{* * *} p<.001$; Bootstrapping: 5,000 replications.

\section{DISCUSSION}

The ongoing COVID-19 crisis has highlighted the critical role that leaders play in dealing with unexpected and threatening events (Bundy, Pfarrer, Short, \& Coombs, 2017; Lagowska, Sobral, \& Furtado, 2020). Research has already shown that leaders are particularly effective in shaping the meaning of the events and the understanding of evolving crises (Sobral, Carvalho, Lagowska, Furtado, \& Grobman, 2020). The present study adds to this literature by examining the role of LMX on alleviating physicians' burnout through its influence on perceived psychosocial job demands and resources, in the extreme context of COVID-19 pandemic.

Our results confirm that the coronavirus pandemic has had an overwhelming impact on hospital systems and personnel. Particularly, our study shows that the COVID-19 disease has put considerable physical and emotional strain on healthcare workers. Burnout thresholds of exhaustion and disengagement were met by $85.9 \%$ and $83.5 \%$ of our respondents, respectively. These findings are similar to others reported in other countries during the pandemic, revealing the widespread impact of the coronavirus disease among healthcare professionals (e.g., Lai, Ma, \& Wang et al., 2020; Tan et al., 2020).

Further, our findings seem to confirm that physicians experience less burnout when they have a high-quality relationship with their leaders. By providing support, attention, information and feedback, leaders can help physicians restore resources needed to cope with stressful circumstances inherent to pandemic situations as well as reduce role stressors that comprise their psychological demands (Thomas \& Lankau, 2009). On the other hand, surprisingly, our results also show that this beneficial effect of LMX is weaker for physicians directly involved with the care provided to COVID-19 patients than for those in less exposed roles.
As we discussed before, frontline physicians are likely to face additional psychological demands arising from having to deal with a more risky, threatening, and constrained work environment. They also suffer a more intense resource depletion at work due to the emotional labor and surface acting needed to cope with such demanding contexts (Xanthopoulou, Oerlemans, \& Koszucka, 2018). Thus, we reasoned that because frontline physicians are in such a precarious and stressful work context, they would find in high-LMX relationships an extraordinary way to recover resources and adjust work demands, which would make the LMX effects stronger. However, our findings reveal that in a context of significant extremeness, high-quality exchanges with the leader seem to have less capability to influence psychosocial stressors at work.

Perhaps this happens because frontline physicians experience a workplace environment where collaborative and interdependent behaviors among members are not only valued, but necessary, which fosters a strong team-oriented culture (Erdogan, Liden, \& Kraimer, 2006). Team-oriented cultures stress getting along with others (i.e., co-workers), and developing trust-based bond with them, which may play a crucial role in helping employees to deal more effectively with work demands and stressors on the job. In such contexts, social support and influence may be supplied by team members, not necessarily by their leaders, which would explain a weaker effect of LMX on job demands and resources for frontline employees. This reasoning is aligned with the notion of "substitutes for leadership" (Kerr \& Jermier, 1978) - factors reducing leaders' ability to influence outcomes by replacing the influence of leader behaviors.

We speculate that another possible explanation can be that the demands and role expectations inherent to high-LMX relationships, which are usually well accepted (Gerstner \& Day, 1997), can become additional role stressors for the COVID-19 
frontline physicians, who are already overwhelmed due to the pandemic, thereby diminishing the beneficial effects of LMX. This is consistent with Scandura and Pellegrini (2008) depiction that "subordinate's high-quality exchanges with the supervisor may no longer counteract the demands of increased workload and stress" (p. 103). Notwithstanding, our finding corroborates Hällgren et al. (2018) claim that extreme contexts may create particularly unique contingencies and constraints that can be a lever for counterfactual reasoning.

Overall, our results show that LMX matters even in extreme contexts. Although the critical role of supportive leadership and leadership behaviors in extreme settings has been recognized (Bundy et al., 2017), this remains one of the least researched areas in the leadership field (Hannah et al., 2009). Accordingly, research that explores the effectiveness of certain styles and behaviors for work outcomes is almost absent. Therefore, the present study contributes to the role of LMX in the wake of an extreme context, such as the COVID-19 pandemic. Further, regardless of the contextualized outlook, by acknowledging how LMX is linked to burnout among medical staff, our study addresses recent calls for research on the role of specific leadership perspectives on psychological syndromes, such as burnout and post-traumatic stress disorder (Kelly \& Hearld, 2020).

The problem of burnout among physicians is particularly troubling because the decreased quality of care given to patients can result in permanent damages, and even the loss of lives. In this regard, from a practitioner standpoint, our results suggest that healthcare organizations should foster high-quality relationships among their medical staff as this is an excellent antidote for diminishing the experience of burnout. For this purpose, leadership training programs could, therefore, highlight ways to improve the relationship quality between medical supervisors and their staff. In this respect, physicians in leadership positions should learn how to treat their colleagues with respect, give sufficient feedback, as well as to identify the needs and development potential of the healthcare workers under their supervision.

As with all correlational research, a limitation of this study is that the causality of relationships could not be determined. We assumed that LMX relationships affect individuals' burnout. However, we cannot exclude the possibility that individuals suffering from burnout reduce their appraisal of their LMX relationships. Also, as we collected data via self-report surveys, we cannot exclude the existence of common-method variance (CMV). To minimize such effect, we included positive and negative affection as control variables in our models, as they are measures of presumed causes of CMV. Nevertheless, future longitudinal research could resolve these issues.

\section{CONCLUSION}

Burnout has become an epidemic in healthcare organizations. According to a survey conducted with more than 15,000 physicians, the prevalence of burnout was found to be around $42 \%$ (Kane, 2020). The COVID-19 pandemic, however, has raised even more concerns about burnout among medical doctors, particularly because societies depend on these professionals to overcome this threat. In this sense, our findings shed light on the role of leadership, particularly LMX, in alleviating burnout in this time of the coronavirus. Specifically, our findings highlight the importance of creating an environment conducive to the construction of positive work relationships based on mutual trust and respect for diminishing harmful psychological syndromes among physicians.

\section{REFERENCES}

Alves, M. G. D. M., Chor, D., Faerstein, E., Lopes, C. D. S., \& Werneck, G. L. (2004). Versão resumida da" job stress scale": Adaptação para o português. Revista de Saúde Pública, 38, 164-171. doi: 10.1590/ So034-89102004000200003

Bakker, A., Demerouti, E., \& Euwema, M. (2005). Job resources buffer the impact of job demands on burnout. Journal of Occupational Health Psychology, 2, 170-180. doi: 10.1037/1076-8998.10.2.170

Bakker, A. B., \& Demerouti, E. (2007). The job demands-resources model: State of the art. Journal of Managerial Psychology, 22, 309328. doi: 10.1108/02683940710733115

Bakker, A. B., \& Demerouti, E. (2008). Towards a model of work engagement. The Career Development International, 13(3), 209-223. doi: $10.1108 / 13620430810870476$

Bansal, P., Bingemann, T. A., Greenhawt, M., Mosnaim, G., Nanda, A., Oppenheimer, J., Sharma, H., David Stukus, D., \& Shaker, M. (2020) Clinician wellness during the Covid-19 pandemic: Extraordinary times and unusual challenges for the allergist/immunologist. Journal of Allergy and Clinical Immunology Practice, 8(6), 1781-1790. doi: 10.1016/j.jaip.2020.04.001

Bundy, J., Pfarrer, M. D., Short, C. E., \& Coombs, W. T. (2017). Crises and crisis management: Integration, interpretation, and research development. Journal of Management, 43(6), 1661-1692.

Carlson, D. S., \& Perrewé, P. L. (1999). The role of social support in the stressor-strain relationship: An examination of workfamily conflict. Journal of Management, 25(4), 513-540. doi: $10.1177 / 0149206316680030$

Côrtes, M., Souza, M., \& Puente-Palacios, K. (2019). Multidimensional measure of leader-member exchange: Psychometric properties of its Brazilian version. Psico-USF, 24(3), 569-581. doi: 10.1590/141382712019240313 
Demerouti, E., Bakker, A., Nachreiner, F., \& Schaufeli, W. (2001). The job demands-resources model of burnout. Journal of Applied Psychology, 86(3), 499-512. doi: 10.1037/0021-9010.86.3.499

Demerouti, E., Mostert, K., \& Bakker, A. B. (2010). Burnout and work engagement: A thorough investigation of the independency of both constructs. Journal of Occupational Health Psychology, 15(3), 209222. doi:10.1037/a0019408

Dicke, T., Stebner, F., Linninger, C., Kunter, M., \& Leutner, D. (2018). A longitudinal study of teachers' occupational well-being: Applying the job demands-resources model. Journal of Occupational Health Psychology, 23(2), 262-277. doi: 10.1037/ocpoooo070

Epitropaki, O., \& Martin, R. (2005). From ideal to real: A longitudinal study of the role of implicit leadership theories on leader-member exchanges and employee outcomes. Journal of Applied Psychology, 9o(4), 659-676. doi: 10.1037/0021-9010.90.4.659

Epitropaki, O, Kapoutsis, I., Ellen, B. P., III, Ferris, G. R., Drivas, K., \& Ntotsi, A. (2016). Navigating uneven terrain: The roles of political skill and LMX differentiation in prediction of work relationship quality and work outcomes. Journal of Organizational Behavior, 37, 1078-1103. doi: 10.1002/job.2100

Erdogan, B., Liden, R., \& Kraimer, M. (2006). Justice and leader-member exchange: The moderating role of organizational culture. Academy of Management Journal, 49(2), 395-406. doi:10.2307/20159770

Fernandes, G., \& Pereira, B. (2020). The challenges of funding the Brazilian health system in fighting the COVID-19 pandemic in the context of the federative pact. Revista de Administração Pública, 54(4), 595-613. doi: 10.1590/0034-761220200290x

Gerstner, C., \& Day, D. (1997). Meta-analytic review of leader-member exchange theory: Correlates and construct issues. Journal of Applied Psychology, 82, 827-844. doi: 10.1037/0021-9010.82.6.827

Gottfredson, R. K., Wright, S. L., \& Heaphy, E. D. (2020). A critique of the Leader-Member Exchange construct: Back to square one. The Leadership Quarterly, 101385. doi:10.1016/j.leaqua.2020.101385

Graen, G. B., \& Uhl-Bien, M. (1995). Relationship-based approach to leadership: Development of leader-member exchange (LMX) theory of leadership over 25 years: Applying a multi-level multi-domain perspective. Leadership Quarterly, 6, 219-247. doi: 10.1016/10489843(95)90036-5

Halbesleben, J., \& Buckley, M. (2004). Burnout in organizational life. Journal of Management, 30, 859-879. doi: 10.1016/j.jm.2004.06.004

Halbesleben, J., \& Demerouti E. (2005). The construct validity of an alternative measure of Burnout. Work \& Stress, 19(3), 208-220. doi: $10.1080 / 02678370500340728$

Hällgren, M., Rouleau, L. \& Rond, M. (2018). A matter of life or death: How extreme context research matters for management and organization studies. Academy of Management Annals, 12(1), 111-153. doi: 10.5465/annals.2016.0017

Hannah, S., Uhl-Bien, M., Avolio, B., \& Cavarretta, F. (2009). A framework for examining leadership in extreme contexts. Leadership Quarterly, 20(6), 897-919. doi: 10.1016/j.leaqua.2009.09.006

Harms, P., Credé, M., Tynan, M., Leon, M., \& Jeung, W. (2017). Leadership and stress: A meta-analytic review. Leadership Quarterly, 28, 178 194. doi: 10.1016/j.leaqua.2016.10.006

Hesselgreaves, H., \& Scholarios, D. (2014). Leader-member exchange and strain: A study of job demands and role status. Human Resource Management Journal, 24(4), 459-478. doi: 10.1111/1748-8583.12042
Hetland, H., Sandal, G. M., \& Johnsen, T. B. (2007). Burnout in the information technology sector: Does leadership matter? European Journal of Work and Organizational Psychology, 16, 58-75. doi: 10.1080/13594320601084558

Hobfoll, S. E. (2002). Social and psychological resources and adaptation. Review of General Psychology, 6(4), 307-324. doi: 10.1037/10892680.6.4.307

Kane, L. (2020). Medscape national physician burnout and suicide report 2020. Retrieved from https://www.medscape.com/slideshow/2020-lifestyle-burnout-6012460

Karasek, R., \& Theorell, T. (1990). Healthy work stress, productivity, and the reconstruction of working life. New York, USA: Basic Books.

Kelly, R. J., \& Hearld, L. R. (2020). Burnout and leadership style in behavioral health care: A literature review. Journal of Behavioral Health Services \& Research, 47, 581-600. doi: 10.1007/s11414-01909679-z

Kerr, S., \& Jermier, J. M. (1978). Substitutes for leadership: Their meaning and measurement. Organizational Behavior and Human Performance, 22(3), 375-403. doi: 10.1016/0030-5073(78)90023-5

Lagowska, U., Sobral, F., \& Furtado, L. (2020). Leadership under crises: A research agenda for the post-Covid-19 Era. Brazilian Administration Review, 17(2), 1-5. doi: 10.1590/1807-7692bar2020200062

Lai, J., Ma, S., Wang, Y., et al. (2020). Factors associated with mental health outcomes among health care workers exposed to coronavirus disease 2019. JAMA Network Open, 3(3), e203976. doi:10.1001/ jamanetworkopen.2020.3976

Liden, R., \& Maslyn, J. (1998). Multidimensionality of leader-member exchange: An empirical assessment through scale development. Journal of Management, 24(1), 43-72. doi: 10.1016/S01492063(99)80053-1

Lu, W., Wang, H., Lin, Y., \& Li, L. (2020). Psychological status of medical workforce during the COVID-19 pandemic: A crosssectional study. Psychiatry Research, 288, 112936. doi: 10.1016/j. psychres.2020.112936

Maslach, C., \& Leiter, M. P. (2008). Early predictors of job burnout and engagement. Journal of Applied Psychology, 93, 498-512. doi: 10.1037/0021-9010.93.3.498

Maslach, C., Schaufeli, W., \& Leiter, M. (2001). Job burnout. Annual Review of Psychology, 52, 397-422. doi: 10.1146/annurev. psych.52.1.397

Montani, F., Courcy, F., \& Vandenberghe, C. (2017). Innovating under stress: The role of commitment and leader-member exchange. Journal of Business Research, 77, 1-13. doi:10.1016/j.jbusres.2017.03.024

Peci, A. (2020). The response of the Brazilian public administration to the challenges of the COVID-19 pandemic. Revista de Administração Pública, 54(4). doi: 10.1590/0034-761242020x

Restauri, N., \& Sheridan, A. (2020). Burnout and posttraumatic stress disorder in the coronavirus disease 2019 (Covid-19) pandemic Journal of the American College of Radiology, 17(7), 921-926. doi: 10.1016/j.jacr.2020.05.021

Sasangohar, F., Jones, S. L. Masud, F. N., Vahidy, F. S., \& Kash, B. A. (2020). Provider burnout and fatigue during the Covid-19 pandemic: Lessons learned from a high-volume intensive care unit. Anesthesia \& Analgesia, 131(1), 106-111. doi: 10.1213/ANE.0000000000004866 
Scandura, T., \& Pellegrini, E. (2008). Trust and leader-member exchange: A closer look at relational vulnerability. Journal of Leadership \& Organizational Studies, 15(2), 101-110. doi: $10.1177 / 1548051808320986$

Schermuly, C. C., \& Meyer, B. (2016). Good relationships at work: The effects of Leader-Member Exchange and Team-Member Exchange on psychological empowerment, emotional exhaustion, and depression. Journal of Organizational Behavior, 37(5), 673-691. doi: 10.1002/ job.2060

Schreibera, M., \& Jenny, G. (2020). Development and validation of the 'Lebender emoticon PANAVA' scale for digitally measuring positive and negative activation and valence via emoticons. Personality \& Individual Differences, 160: 10992. doi: 10.1016/j.paid.2020.109923

Schuster, M., \& Dias, V. (2018). Oldenburg burnout inventory: Validação de uma nova forma de mensurar burnout no Brasil. Ciência \& Saúde Coletiva, 23(2), 553-562. doi: 10.1590/1413-81232018232.27952015

Silva, G., Saraiva, E., Ferreira, G., Peixoto Junior, R., \& Ferreira, L. (2020). Healthcare system capacity of the municipalities in the State of Rio de Janeiro: Infrastructure to confront COVID-19. Revista de Administração Pública, 54(4), 578-594. doi: 10.1590/0034-761220200128x

Siu, O. L., Lu, C. Q., \& Spector, P. E. (2007). Employees' well-being in Greater China: The direct and moderating effects of general selfefficacy. Applied Psychology, 56(2), 288-301. doi: 10.1111/j.14640597.2006.00255.x

Sobral, F., Carvalho, J., Lagowska, U., Furtado, L., \& Grobman, M. (2020). Better safe than sorry: Leadership sensemaking in the time of Covid-19. Revista de Administração Pública, 54(4), 758-781. doi: 10.1590/0034-761220200262x
Sonnentag, S., Kuttler, I., \& Fritz, C. (2010). Job stressors, emotional exhaustion, and need for recovery: A multi-source study on the benefits of psychological detachment. Journal of Vocational Behavior, 76(3), 355-365. doi: 10.1016/j.jvb.2009.06.005

Tan, B. Y., Abhiram, K., Lim, L. J., Tan, M., Chua, Y. X., Tan, L., ... \& Kinross, J. (2020).. Burnout and associated factors amongst healthcare workers in Singapore during the Covid-19 pandemic. Journal of the American Medical Directors Association. In press. doi:10.1016/j. jamda.2020.09.035.

Thomas, C., \& Lankau, M. (2009). Preventing burnout: The effects of LMX and mentoring on socialization, role stress, and burnout. Human Resource Management, 48(3), 417-432. doi: 10.1002/hrm.20288

Tordera, N., González-Romá, V., \& Peiró, J. M. (2008). The moderator effect of psychological climate on the relationship between leader member exchange (LMX) quality and role overload. European Journal of Work and Organizational Psychology, 17(1), 55-72. doi: $10.1080 / 13594320701392059$

Trépanier, S. G., Fernet, C., \& Austin, S. (2013). The moderating role of autonomous motivation in the job demands-strain relation: A two sample study. Motivation and Emotion, 37(1), 93-105. doi: 10.1007/ S11031-012-9290-9

Tummers, L.G. \& Knies, E. (2013). Leadership and meaningful work in the public sector. Public Administration Review, 73(6), 859-868. doi: 10.1111/puar.12138

Xanthopoulou, D., Oerlemans, W., \& Koszucka, M. (2018). Need for recovery after emotional labor: Differential effects of daily deep and surface acting. Journal of Organizational Behavior, 39(4), 481-494. doi: $10.1002 /$ job.2245

\section{AUTHORS' CONTRIBUTIONS}

Eduardo Moura, Liliane Furtado e Filipe Sobral worked on the conceptualization and theoretical-methodological approach. The theoretical review was conducted by Liliane Furtado. Data collection and analysis was conducted by Eduardo Moura. Filipe Sobral coordinated the writing and final revision of the manuscript. 